\title{
Lysophospholipase $A_{2}$ activity in guinea-pig heart microsomal fractions displaying high activities with 2-acylglycerophosphocholines with linoleic and arachidonic acids
}

\author{
Gilbert ARTHUR \\ Department of Biochemistry and Molecular Biology, Faculty of Medicine, University of Manitoba, Winnipeg, Manitoba, \\ Canada R3E OW3
}

\begin{abstract}
Lysophospholipases $A_{1}$ which catalyse the hydrolysis of acyl groups from 1-acylglycerophosphocholine (GPC) have been characterized in a number of mammalian tissues and do not exhibit any acyl specificity. In the present study lysophospholipase activity in guinea-pig heart microsomes (microsomal fractions) that hydrolyses 2-acyl-GPC was detected and characterized. The enzyme showed a high degree of acyl specificity. The relative rates of hydrolysis of individual 2-acyl-GPCs with different fatty acids was as follows: $\mathrm{C}_{18: 2} / \mathrm{C}_{20: 4} / \mathrm{C}_{18: 1} / \mathrm{C}_{16: 0}, 14: 6: 1: 1$. When substrates were presented in pairs, the hydrolysis of each substrate by the enzyme was inhibited, but to very different extents. Of each pair of lysolipids examined (2-arachidonoyl- and 2-palmitoyl-GPC; 2-arachidonoyl- and 2-linoleoyl-GPC), the one with the expected higher rate of hydrolysis was more severely inhibited and the degree of inhibition was dependent on the concentration of the other lysolipid. The characteristics of the lysophospholipase $A_{2}$ suggest the enzyme could work in concert with phospholipase $A_{1}$ to release arachidonic and linoleic acids for further metabolism. The properties of lysophospholipase $A_{2}$ and $A_{1}$ suggest that they are different enzymes.
\end{abstract}

\section{INTRODUCTION}

It is now well established that the availability of free arachidonic acid in tissues constitutes the limiting factor in the biosynthesis of eicosanoids [1]. In mammalian tissues, arachidonic acid is esterified at the C-2 position of phospholipids, from which it is released for eicosanoid synthesis. The mechanism of release is widely thought to be via $\mathrm{Ca}^{2+}$-activated phospholipase $\mathrm{A}_{2}[1,2]$. In cardiovascular tissues, prostacyclin may act together with lipoxygenase products of linoleic acid to prevent the clogging of vessels $[3,4]$. Linoleic acid is also esterified to cardiac phospholipids [5,6], from which it must be mobilized for metabolism. The mode of linoleate mobilization is not known, but is presumed to be mediated by phospholipase $A_{2}$. Recent evidence $[7,8]$ suggests the existence of pathways for the selective release of arachidonate in the absence of $\mathrm{Ca}^{2+}$ mobilization, presumably involving enzymes other than phospholipase $A_{2}$, but the nature of these pathways is not known. Potential mechanisms for the release of arachidonate other than via phospholipase $A_{2}$ have been suggested $[2,9]$, but these have not been explored. The initial hydrolysis of a phospholipid by phospholipase $A_{1}$ or plasmalogenase, followed by lysophospholipase hydrolysis of the resultant 2-lysophospholipid, could potentially serve to liberate arachidonate or linoleate. Such controlled release of fatty acids could be regulated through the acyl specificities of one or both enzymes. Phospholipases $A_{1}$ were not thought to possess any specificity for different molecular species of phospholipids [10], but a recently purified phospholipase from hamster heart was found to possess phospholipase $A_{1}$ activity that was specific for phosphatidylcholine with arachidonate esterified at the $\mathrm{C}-2$ position [11].
Lysophospholipases have traditionally been studied with 1-acyl-glycerophospholipids (GPL) as substrate and have not revealed any pronounced preference for substrates with different acyl groups [12-15]. The lysophospholipases participating in any selective release of fatty acids would be expected to hydrolyse fatty acids from 2-acyl-GPL. Therefore the lack of acyl specificity of the enzymes that hydrolyse 1-acyl-GPC, lysophospholipases $A_{1}$, does not preclude the existence of 2-acylGPC hydrolysing enzymes (lysophospholipases $A_{2}$ ) that exhibit acyl specificity. Lysophospholipases $A_{2}$ have rarely been differentiated from lysophospholipase $A_{1}[16]$ and the former have not been well studied or characterized. Rat liver cytosolic lysophospholipase $A_{2}$ activity did not show any preference between 2-stearoylGPC and 2-oleoyl-GPC and was half as active as the lysophospholipase $A_{1}$ [12]. In view of the paucity of information on lysophospholipase $A_{2}$ and their potential role in the release of fatty acids from phospholipids, the present studies were undertaken to characterize activities in guinea-pig heart microsomes (microsomal fractions) that hydroylses 2-acyl-GPC. The ability of lysophospholipase $\mathrm{A}_{2}$ to discriminate between different molecular species of 2-acyl-GPC was also examined.

\section{MATERIALS AND METHODS}

$\left[5,6,8,9,11,12,14,15-{ }^{3} \mathrm{H}\right]$ Arachidonic acid, $\left[9,10(\mathrm{n}){ }^{3} \mathrm{H}\right]-$ palmitic acid, $\left[9,10(\mathrm{n}){ }^{-3} \mathrm{H}\right]$ oleic acid, 1-palmitoyl-2$\left[1-{ }^{14} \mathrm{C}\right]$ linoleoyl L-3-phosphatidylcholine, 1-palmitoyl-2$\left[1-{ }^{14}\right.$ C]palmitoyl L-3-phosphatidylcholine and $1-\left[1-{ }^{14} \mathrm{C}\right]-$ palmitoyl L-lyso-3-phosphatidylcholine were obtained from Amersham International. Lysophosphatidylcholine (1-acyl-GPC, pig liver) was the product of Serdary

Abbreviations used: GPC, sn-glycero-3-phosphocholine; DTT, dithiothreitol; NEM, $N$-ethylmaleimide; DTNB, 5,5'-dithiobis-(2-nitrobenzoic acid); GPL, glycerophospholipids.

Vol. 261 
Laboratories, London, Ontario, Canada. Palmitic acid, stearic acid, oleic acid, linoleic acid and arachidonic acid were purchased from NuChek Prep, Elysian, MN, U.S.A. 5,5'-Dithiobis-(2-nitrobenzoic acid) (DTNB) was obtained from ICN Pharmaceuticals. Guinea pigs $(250-300 \mathrm{~g})$ were obtained from Charles River, Ontario, Canada. DEAE-Sepharose was purchased from Pharmacia. All other chemicals and solvents were of reagent grade and were obtained from Fisher Scientific.

\section{Subcellular fractionation}

Six to eight guinea-pig hearts were used for each experiment. Microsomes were prepared by differential centrifugation and their purity monitored as previously described [6]. The protein content of the fraction was measured by the method of Lowry et al. [17], with bovine serum albumin as standard.

\section{Synthesis of phosphatidylcholine}

The synthesis and purification of phosphatidylcholine was carried out by the method of Hermetter \& Paltauf [18], with slight modifications [19]. 1-Acyl-GPC and radiolabelled fatty acids (arachidonic, oleic and palmitic acids) were used as precursors for the synthesis. Phosphatidylcholine with linoleic acid at the $\mathrm{C}-2$ position was synthesized with non-radioactive linoleic acid and mixed with 1-palmitoyl-2-[1- $\left.{ }^{14} \mathrm{C}\right]$ linoleoyl phosphatidylcholine purchased from Amersham International. The phosphorus content of the purified products was determined by the method of Bartlett [20] and radioactivity was measured by scintillation counting.

\section{Preparation of 2-acyl-GPC}

Phospholipase $A_{1}$ was prepared from guinea-pig pancreas cytosol by the method of Colard et al. [21]. The positional specificity of the enzyme was investigated as previously described [21] with $1-\left[1-{ }^{14} \mathrm{C}\right]$ palmitoyl L-lyso3-phosphatidylcholine and 1-acyl- $\left[2{ }^{3} \mathrm{H}\right]$ arachidonoylGPC as substrates and shown to have the expected specificity. 2-Acyl-GPC was prepared by incubating the radiolabelled phosphatidylcholine synthesized above $(30 \mu \mathrm{mol})$ with $0.2 \mathrm{M}$-Tris $/ \mathrm{HCl}, \mathrm{pH} 8.0,2.4 \mathrm{~mm}$-sodium deoxycholate and guinea-pig pancreas phospholipase $\mathrm{A}_{1}$ (6 mg of protein) in a total volume of $6 \mathrm{ml}$. Incubation was at $37^{\circ} \mathrm{C}$ for $2 \mathrm{~h}$. The reaction was terminated by the addition of $12 \mathrm{ml}$ of chloroform/methanol $(2: 1, \mathrm{v} / \mathrm{v})$. The phases were separated and the lower phase dried and resuspended in chloroform. Lysophosphatidylcholine was purified by silicic acid chromatography [23]. The yields of 2-acyl-GPC obtained by this procedure ranged from 55 to $80 \%$. Unless otherwise specified in the legends, the specific radioactivities of the substrates were as follows; 2-[ $\left.{ }^{3} \mathrm{H}\right]$ arachidonyl-GPC, $0.17 \mathrm{Ci} / \mathrm{mol}$; $2-\left[{ }^{14} \mathrm{C}\right]$ linoleoyl-GPC, $0.15 \mathrm{Ci} / \mathrm{mol} ; 2-\left[{ }^{3} \mathrm{H}\right]$ oleoyl-GPC, $0.19 \mathrm{Ci} / \mathrm{mol} ; 2-\left[{ }^{3} \mathrm{H}\right]$ palmitoyl-GPC, $0.57 \mathrm{Ci} / \mathrm{mol}$.

\section{Lysophospholipase assays}

Lysophospholipase activity was determined by measuring the release of radiolabelled fatty acids from 1-acylGPC and 2-acyl-GPC. The assay mixture contained $100 \mathrm{~mm}$-Tris/HCl, pH 8, $300 \mu \mathrm{M}$-acyl-GPC or $175 \mu \mathrm{M}$-1acyl GPC, and $200 \mu \mathrm{g}$ of guinea-pig heart microsomal protein, in a total volume of $500 \mu$ l. The reaction was initiated by the addition of the substrate, and incubation was at $37^{\circ} \mathrm{C}$ for $10-15 \mathrm{~min}$ in a shaking water bath. The reaction was stopped by the addition of $3 \mathrm{ml}$ of

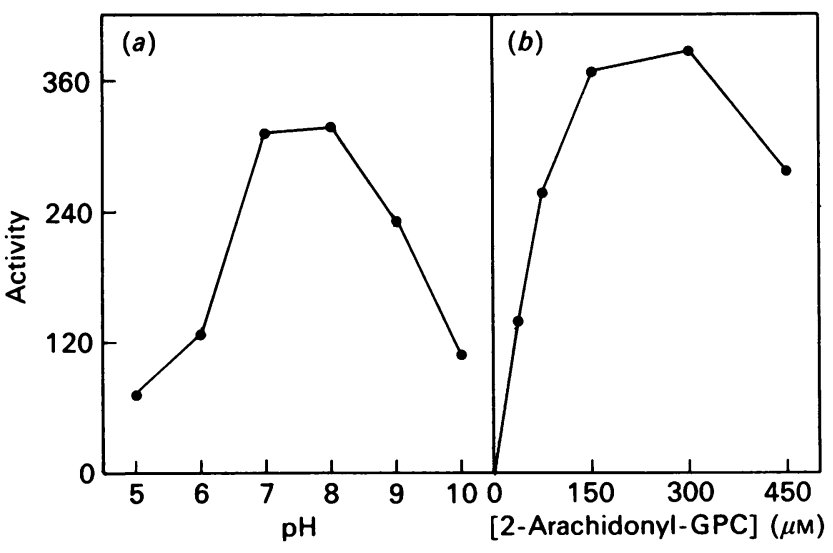

Fig. 1. Effect of $\mathbf{p H}$ and 2-arachidonoyl-GPC concentration on guinea-pig heart lysophospholipase $\mathrm{A}_{2}$ activity

(a) The activity of guinea-pig heart microsomal lysophospholipase $\mathrm{A}_{2}$ activity was determined at different $\mathrm{pH}$ values. The buffers used were Tris/succinate (pH 5-6) and tris $/ \mathrm{HCl}$ (pH 7-10). Enzyme activities were determined with $200 \mu \mathrm{g}$ of microsomal protein, $100 \mathrm{~mm}$-Tris buffer, $400 \mathrm{nmol}$ of 2-arachidonoyl-GPC in a total volume of $500 \mu \mathrm{l}$. The reaction mixture was incubated for $30 \mathrm{~min}$ at $37^{\circ} \mathrm{C}$. The reaction products were isolated by t.l.c. as described in the Materials and methods section. The enzyme activity is expressed as nmol of arachidonic acid produced/h per mg of protein. (b) The activity of guineapig heart microsomal activity was determined as a function of 2-arachidonoyl-GPC concentration. The assay mixture contained $100 \mathrm{~mm}$-Tris/ $\mathrm{HCl}, \mathrm{pH} 8,200 \mu \mathrm{g}$ of microsomal protein and various concentrations of 2-arachidonoylGPC. The mixture was incubated for $15 \mathrm{~min}$ at $37^{\circ} \mathrm{C}$. The enzyme activity is expressed as nmol of arachidonic acid produced/h per mg of protein. Values are means for three separate experiments, each done in duplicate.

chloroform/methanol $(2: 1, \mathrm{v} / \mathrm{v})$ followed by $1 \mathrm{ml}$ of $\mathrm{KCl}(0.9 \%)$. Aliquots of the lower phase were removed, and the reaction products were separated by t.l.c. by using, as solvent system, heptane/di-isopropyl ether/ acetic acid (15:10:1, by vol.). The bands were revealed with $I_{2}$ vapour, and the radioactivity associated with the fatty acid band was determined by scintillation counting on a Beckman LS 3801 counter.

\section{RESULTS}

The main thrust of this investigation was to detect and characterize enzymes hydrolysing 2-acyl-GPC in the guinea-pig heart microsomes with a view to evaluating their possible involvement in the selective release of fatty acids from phospholipids. It was therefore essential to ensure that the substrates used in the study did indeed have the radiolabelled fatty acids at the C-2 position. Purified 2-acyl-GPC was therefore incubated with the guinea-pig pancreas phospholipase $A_{1}$ by using the reaction conditions described in the Materials and methods section. Control incubations were conducted simultaneously with $1-\left[1-{ }^{14} \mathrm{C}\right]$ palmitoyl L-lyso-3-phosphatidylcholine as well as 1-stearoyl-2-[ $\left.{ }^{3} \mathrm{H}\right]$ arachidonoylGPC. The results of incubations with 2-acyl-GPC showed that there was no release of labelled fatty acid, whereas with $1-\left[{ }^{14} \mathrm{C}\right]$ palmitoyl-GPC there was substantial release of labelled fatty acid. In contrast, incubations 
Table 1. Effect of cations on guinea-pig heart microsomal lysophospholipase $\mathbf{A}_{2}$

Lysophospholipase $A_{2}$ activity was assayed with $100 \mathrm{~mm}$ Tris/HCl, $\mathrm{pH} 8,300 \mu \mathrm{M}$-2-arachidonoyl-GPC, $200 \mu \mathrm{g}$ of microsomal protein and the appropriate additions as indicated below, in a total volume of $500 \mu \mathrm{l}$. The mixture was incubated at $37^{\circ} \mathrm{C}$ for $15 \mathrm{~min}$ and the reaction products isolated by t.l.c. as described in the Materials and methods section. The results are expressed as a percentage of the activities obtained in the presence of 2 mM-EDTA and -EGTA. Values are means \pm S.D. for three separate experiments, each of which was done in duplicate.

\begin{tabular}{lc}
\hline Addition & $\begin{array}{c}\text { Lysophospholipase } \mathrm{A}_{2} \\
\text { activity }(\%)\end{array}$ \\
\hline EDTA/EGTA (2 mM) & 100 \\
$\mathrm{Ca}^{2+}(5 \mathrm{mM})$ & $106 \pm 9$ \\
$\mathrm{Mg}^{2+}(5 \mathrm{mM})$ & $105 \pm 7$ \\
$\mathrm{Cu}^{2+}(5 \mathrm{mM})$ & $1 \pm 0.8$ \\
$\mathrm{Zn}^{2+}(5 \mathrm{mM})$ & $0.2 \pm 1$
\end{tabular}

Table 2. Effect of thiol reagents on guinea-pig heart microsomal lysophospholipase $A_{1}$ and $A_{2}$ activities

Lysophospholipase $A_{1}$ and $A_{2}$ activities were measured with $175 \mu \mathrm{M}$-1-acyl-GPC and $300 \mu \mathrm{M}$-2-arachidonoyl-GPC respectively. The microsomes $(200 \mu \mathrm{g})$ were incubated with the additions for $10 \mathrm{~min}$ before the addition of the appropriate lysophosphatidylcholine to initiate the reaction. The reaction mixture was incubated at $37 \mathrm{C}$ for $15 \mathrm{~min}$. The reaction products were isolated by t.l.c. as described in the Materials and methods section. The results are expressed as a percentage of the activity obtained in the absence of any addition (control). The values are the mean \pm S.D. of three separate reactions each assayed in duplicate.

\begin{tabular}{lcc}
\hline $\begin{array}{l}\text { Addition } \\
(0.5 \mathrm{mM})\end{array}$ & $\begin{array}{c}\text { Lysophospholipase } \\
\mathrm{A}_{2} \text { activity } \\
(\% \text { of control) }\end{array}$ & $\begin{array}{c}\text { Lysophospholipase } \\
\mathrm{A}_{1} \text { activity } \\
(\% \text { of control) }\end{array}$ \\
\hline None & 100 & 100 \\
DTT & $90 \pm 12$ & $89 \pm 9$ \\
GSH & $100 \pm 7$ & $95 \pm 5$ \\
Iodoacetate & $121 \pm 6$ & $98 \pm 10$ \\
NEM & $18 \pm 5$ & $22 \pm 7$ \\
DTNB & $11 \pm 7$ & $18 \pm 6$
\end{tabular}

with 1-stearoyl-2-[ $\left.{ }^{3} \mathrm{H}\right]$ arachidonoyl-GPC resulted in the association of label with the lysophosphatidylcholine fraction and none in the fatty acid fraction. Further characterization was achieved by acylating the lysolipids to phosphatidylcholine with arachidonoyl-CoA using guinea-pig liver microsomes. The phosphatidylcholine was isolated and hydrolysed with phospholipase $A_{2}$ [from snake (Crotalus adamenteus) venom]. The distribution of label in the fatty acid and lysophosphatidylcholine fractions was then determined. Details of the procedures were described in the preceding paper [24]. The results showed that at least $97 \%$ of the label was associated with the fatty acid fraction. These experiments clearly established that the substrates used in the studies below were indeed 2-acyl-GPC and that little acyl migration
Table 3. Acyl specificity of guinea pig heart microsomal lysophospholipase $\mathbf{A}_{2}$

2-Acyl-GPCs with different radiolabelled fatty acids were synthesized as described in the Materials and methods section. Substrate ( $300 \mu \mathrm{M}$ of each one) was incubated with $200 \mu \mathrm{g}$ of microsomal protein, $100 \mathrm{~mm}$-Tris $/ \mathrm{HCl}, \mathrm{pH} 8$, in a reaction volume of $500 \mu$ l. The mixture was incubated at $37^{\circ} \mathrm{C}$ for $15 \mathrm{~min}$. The reaction products were isolated as described in the Materials and methods section. The results are means \pm S.D. for four separate experiments, each of which was done in triplicate. Abbreviations: $C_{16: 0}$, palmitoyl; $\mathrm{C}_{18: 1}$, oleoyl; $\mathrm{C}_{18: 2}$, linoleoyl; $\mathrm{C}_{20: 4}$, arachidonyl.

\begin{tabular}{lcc}
\hline & $\begin{array}{c}\text { Specific activity } \\
\text { (nmol of fatty } \\
\text { acid produced/h } \\
\text { per mg of } \\
\text { protein) }\end{array}$ & $\begin{array}{c}\text { Activity relative } \\
\text { to } 2-\mathrm{C}_{16: 0} \text {-GPC } \\
\text { hydrolysis }\end{array}$ \\
Substrate & $62.6 \pm 4$ & \\
\hline $2-\mathrm{C}_{16: 0}-$ GPC & $75.4 \pm 6$ & 1 \\
$2-\mathrm{C}_{18: 1}$-GPC & $848.8 \pm 66$ & 1.2 \\
$2-\mathrm{C}_{18: 2}$-GPC & $351.8 \pm 44$ & 13.6 \\
$2-\mathrm{C}_{20: 4}$-GPC & & 5.6 \\
\hline
\end{tabular}

had occurred during the preparation and purification of the substrates. The 2-acyl-GPC were stored at $-20^{\circ} \mathrm{C}$ and utilized within 3 days of synthesis, a period which we determined not to result in any significant acyl migration. Substrates stored for more than 3 days were rehydrolysed with guinea-pig pancreas phospholipase $A_{1}$ and purified.

After exploratory experiments with $2-\left[{ }^{3} \mathrm{H}\right]$ arachidonoyl-GPC had indicated the presence of a lysophospholipase $A_{2}$ activity in guinea-pig heart microsomes the optimum conditions for the assay of the enzyme were established. The optimal $\mathrm{pH}$ range was 7-8 (Fig. 1) and the optimal 2-arachidonoyl-GPC concentration was $150-300 \mu \mathrm{M}$ with $200 \mu \mathrm{g}$ of microsomal protein (Fig. 1). A similar range for optimal activity was obtained with 2-palmitoyl-GPC as substrate (results not shown). The reaction rate was linear for $20 \mathrm{~min}$.

The effects of bivalent cations on the activity of the lysophospholipase $A_{2}$ activity were examined (Table 1). The enzyme did not exhibit any requirement for bivalent cations and the addition of $\mathrm{Ca}^{2+}$ and $\mathrm{Mg}^{2+}(5 \mathrm{mM})$ did not affect the activity. $\mathrm{Cu}^{2+}$ and $\mathrm{Zn}^{2+}$, on the other hand, severely inhibited the activity of the enzyme. However, this may be due to an observed aggregation of the membranes in the presence of the cations before the addition of the substrate. The effect of thiol reagents on the hydrolysis of 2-[ $\left.{ }^{3} \mathrm{H}\right]$ arachidonoyl-GPC was also studied (Table 2). Addition of DTT (0.5 mM) and GSH $(0.5 \mathrm{~mm})$ to the incubation mixtures did not affect the enzyme activity, but DTNB and NEM, which block thiol groups, severely inhibited the activity of the enzyme. Surprisingly, the alkylating agent iodoacetate enhanced the activity of the lysophospholipase $A_{2}$ by $20 \%$, even though it would be expected to block thiol groups.

The acyl specificity of the lysophospholipase $A_{2}$ was investigated and the results obtained are shown in Table 3. The enzyme showed marked differences in the rates of hydrolysis of substrates with different acyl groups. The order of specificity for 2-acyl-GPC substrates was as follows:

$$
\text { Linoleate }>\text { arachidonate } \gg \text { oleate }=\text { palmitate }
$$


Table 4. Effect of presenting mixtures of 2-acyl-GPCs on guinea-pig microsomal lysophospholipase $\mathbf{A}_{2}$ activity

$2-\left[{ }^{14} \mathrm{C}\right]$ Palmitoyl $\left(\mathrm{C}_{16: 0}\right)-\mathrm{GPC}$ (sp. radioactivity $0.2 \mathrm{Ci} / \mathrm{mol}$; $120 \mu \mathrm{M})$ and $2-\left[{ }^{3} \mathrm{H}\right]$ arachidonoyl $\left(\mathrm{C}_{20: 4}\right)-\mathrm{GPC}$ (sp. radioactivity $0.33 \mathrm{Ci} / \mathrm{mol} ; 120 \mu \mathrm{M}$ ) were incubated with $200 \mu \mathrm{g}$ of guinea-pig heart microsomal protein, $100 \mu \mathrm{M}$-Tris $/ \mathrm{HCl}$, $\mathrm{pH} 8$, in a reaction volume of $500 \mu$. The reaction was initiated by the addition of microsomes. The mixture was incubated at $37^{\circ} \mathrm{C}$ for $15 \mathrm{~min}$. The reaction products were isolated as described in the Materials and methods section. Experiments were also conducted with $120 \mu \mathrm{M}-2-\left[{ }^{3} \mathrm{H}\right]-$ arachidonoyl-GPC (sp. radioactivity $0.33 \mathrm{Ci} / \mathrm{mol}$ ) and $120 \mu \mathrm{M}-2-\left[{ }^{14} \mathrm{C}\right]$ linoleoyl $\left(\mathrm{C}_{18: 2}\right)$-GPC (sp. radioactivity $0.15 \mathrm{Ci} / \mathrm{mol}$ ). Control experiments were conducted with $120 \mu \mathrm{M}$ of each individual substrate. The results represent the means for two separate experiments, each of which was carried out in triplicate.

\begin{tabular}{lccc}
\hline & \multicolumn{3}{c}{$\begin{array}{c}\text { Specific activity (nmol of fatty acid } \\
\text { produced } / \mathrm{h} \text { per mg of protein) }\end{array}$} \\
\cline { 2 - 4 } Substrate(s) & {$\left[{ }^{14} \mathrm{C}\right] \mathrm{C}_{16: 0}$} & {$\left[{ }^{3} \mathrm{H}\right] \mathrm{C}_{20: 4}$} & {$\left[{ }^{14} \mathrm{C}\right] \mathrm{C}_{18: 2}$} \\
\hline Control & 40.9 & 239 & 520 \\
$2-\mathrm{C}_{16: 0}$-GPC & 31.6 & 34 & - \\
$+2-\mathrm{C}_{20: 4}$-GPC & & 193 & 182 \\
$2-\mathrm{C}_{18: 2}-\mathrm{GPC}$ & - & & \\
$+2-\mathrm{C}_{20: 4}$-GPC & & &
\end{tabular}

The rate of hydrolysis of 2-linoleate-GPC was twice as high as that with 2-arachidonoyl-GPC and 14 times that with 2-palmitoyl-GPC. The ability of the enzyme to maintain this selectivity when presented with two substrates simultaneously was also examined (Table 4). Incubation of the microsomes with $2-\left[{ }^{3} \mathrm{H}\right]$ arachidonoylGPC $(120 \mu \mathrm{M})$ and $2-\left[{ }^{14} \mathrm{C}\right]$ palmitoyl-GPC $(120 \mu \mathrm{M})$ resulted in an $87 \%$ decrease in the activity of the enzyme for 2-arachidonoyl-GPC, but only a $20 \%$ decrease for 2-palmitoyl-GPC compared with the rates obtained with the individual substrates. With $2-\left[{ }^{3} \mathrm{H}\right]$ arachidonoylGPC $(120 \mu \mathrm{M})$ and $2-\left[{ }^{14} \mathrm{C}\right]$ linoleoyl-GPC $(120 \mu \mathrm{M})$, the hydrolysis of the latter was inhibited $65 \%$, whereas hydrolysis of the former was inhibited by $19 \%$. In both situations hydrolysis of the substrate with the expected higher rate of hydrolysis (Table 4) was more severely inhibited. The above experiments were conducted with $120 \mu \mathrm{M}$ of each substrate to avoid the possible inhibition of the enzyme by higher concentrations of lysolipids; however, an experiment conducted with $240 \mu \mathrm{M}$ each of 2-palmitoyl- and 2-arachidonoyl-GPC yielded results very similar to those described above. The inhibition described above was concentration-dependent (Fig. 2). For example a 2-arachidonoyl-GPC/2-linoleoyl-GPC molar ratio of 0.07 resulted in an insignificant inhibition of 2-linoleoyl-GPC hydrolysis compared with 27 and $46 \%$ inhibition at molar ratios of 0.13 and 0.33 respectively.

Lysophospholipase $A_{1}$ activity is present in the microsomal fraction of mammalian hearts, including the guinea-pig heart [25-27]. The optimal conditions required to assay this enzyme were determined (Fig. 3). The optimal $\mathrm{pH}$ range for the hydrolysis of 1-acyl-GPC was $\mathrm{pH}$ 7-8 and was similar to that required for the hydrolysis of 2-acyl-GPC. The maximal hydrolysis of 1-acyl-GPC was obtained at a substrate concentration of $170 \mu \mathrm{M}$, and

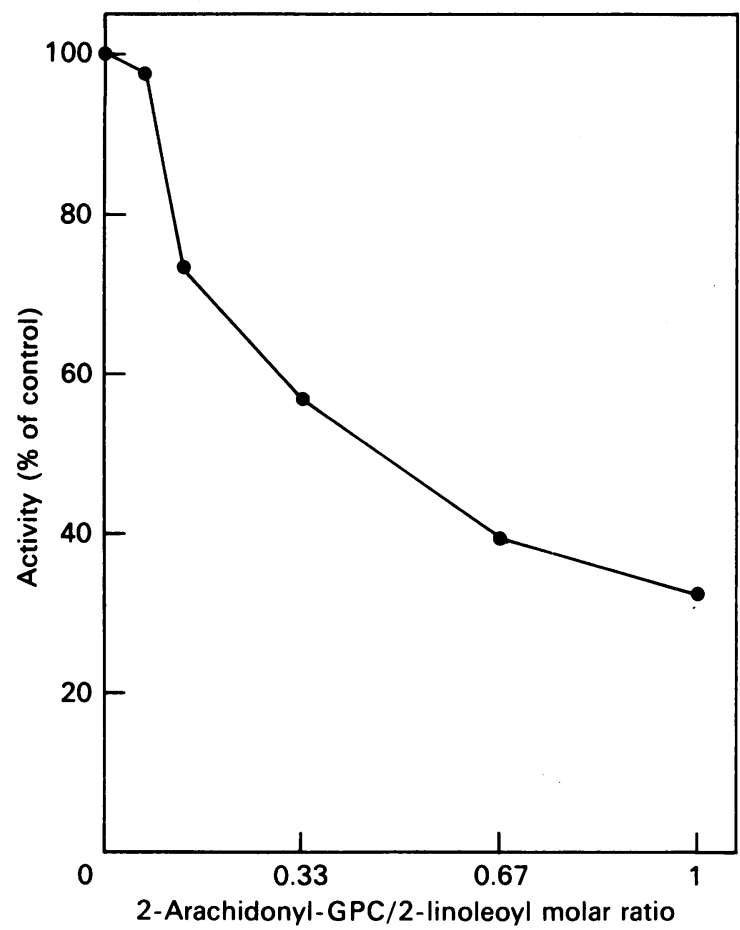

Fig. 2. Effect of varying the 2-linoleoyl-GPC/2-arachidonoylGPC molar ratio on the hydrolysis of 2-linoleoyl-GPC by guinea-pig heart microsomal lysophospholipase $\mathbf{A}_{2}$

The hydrolysis of $120 \mu \mathrm{M}-2-\left[{ }^{14} \mathrm{C}\right]$ linoleoyl-GPC by guineapig heart microsomal lysophospholipase $A_{2}$ was measured in the presence of different concentrations of 2arachidonoyl-GPC $(0-120 \mu \mathrm{M})$. The reaction mixture contained $100 \mathrm{~mm}$-Tris $/ \mathrm{HCl}, \mathrm{pH} 8$, and $200 \mu \mathrm{g}$ of microsomal protein in a total volume of $500 \mu \mathrm{l}$. Incubation was at $37^{\circ} \mathrm{C}$ for $15 \mathrm{~min}$. The reaction products were isolated by t.l.c. as described in the Materials and methods section. The activities are expressed as a percentage of the activity obtained in the absence of 2-arachidonoyl-GPC. Values are means for two separate experiments, each of which was carried out in triplicate.

concentrations of greater than $170 \mu \mathrm{M}$ resulted in an inhibition of the reaction. This contrasts with the optimum substrate concentration of $300 \mu \mathrm{M}$ obtained for 2-acyl-GPC. Incubations carried out at the optimal conditions for each activity with 1-palmitoyl-GPC and 2-arachidonoyl-GPC for lysophospholipases $A_{1}$ and $A_{2}$ respectively indicated that both substrates were hydrolysed at comparable rates.

Fatty acids inhibit the activity of lysophospholipase $A_{1}$ $[13,25,26,28]$. The effect of palmitic, stearic, oleic, linoleic and arachidonic acids $(100 \mu \mathrm{M})$ on lysophospholipase $A_{1}$ and $A_{2}$ activities was therefore investigated. Clear solutions of fatty acids were prepared by sonication before addition to the incubation mixture. The degree of inhibition of lysophospholipase $A_{1}$ activity by the fatty acids was greater than that observed for lysophospholipase $A_{2}$, regardless of the fatty acid species (Table 5). This differential inhibition of the two lysophospholipases by fatty acids was observed with 1-palmitoyl-GPC as the substrate for lysophospholipase $A_{1}$ and 2-arachidonoylGPC or 2-palmitoyl-GPC as substrates for lysophospholipase $A_{2}$. The observation could therefore not be attributed to differences in the acyl composition of their respective substrates. The specific activities of the 


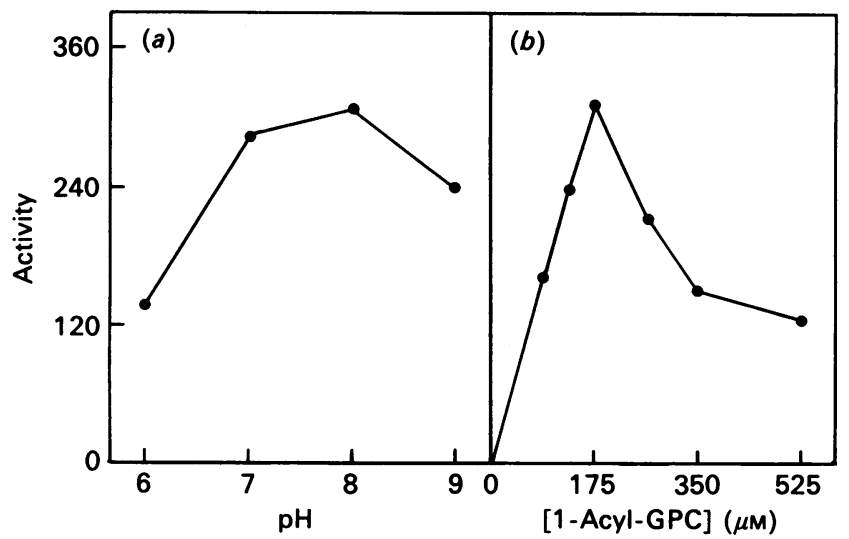

Fig. 3. Effect of pH and 1-acyl-GPC concentration on guinea-pig heart lysophospholipase $A_{1}$ activity

(a) The activity of guinea-pig heart microsomal lysophospholipase $A_{1}$ activity was determined at different $\mathrm{pH}$ values. The buffers used were similar to those described above in Fig. 1. The reaction was determined with $200 \mu \mathrm{g}$ of protein, $100 \mathrm{~mm}$-Tris buffer and $175 \mathrm{~mm}-1$-acyl-GPC in a total volume of $500 \mu \mathrm{l}$. The reaction mixture was incubated for $15 \mathrm{~min}$ at $37^{\circ} \mathrm{C}$. Enzyme activity is expressed as nmol of fatty acid released/h per $\mathrm{mg}$ of protein. (b) The activity of guinea-pig heart microsomal lysophospholipase $A_{1}$ activity was measured as a function of 1-acyl-GPC concentration. The assay mixture contained $100 \mathrm{~mm}$ Tris $/ \mathrm{HCl}, \quad \mathrm{pH} 8,200 \mu \mathrm{g}$ of protein and various concentrations of 1-acyl-GPC. The reaction mixture was incubated at $37^{\circ} \mathrm{C}$ for $15 \mathrm{~min}$. The enzyme activity is expressed as nmol of fatty acid produced/h per $\mathrm{mg}$ of protein. Values are means of two separate experiments, each of which was done in duplicate.

Table 5. Effect of fatty acids on guinea-pig heart microsomal lysophospholipase $A_{2}$ and $A_{1}$ activities

Lysophospholipase $A_{2}$ and $A_{1}$ were assayed in the presence of $100 \mu \mathrm{M}$ of various fatty acids. Lysophospholipase $A_{2}$ activity was assayed with either $300 \mu \mathrm{M}$-2-arachidonoyl$\left(C_{20: 4}\right)$-GPC or -2-palmitoyl $\left(C_{16: 0}\right)$-GPC, whereas lysophospholipase $A_{1}$ activity was assayed with $175 \mu \mathrm{M}-1$ palmitoyl-GPC. The reaction conditions and the extraction of the reaction products are described in detail in the Materials and methods section. The results are expressed as a percentage of the activities obtained in the absence of fatty acids (control). Values are means \pm S.D. for three separate experiments each of which was done in duplicate. Further abbreviations: $\mathrm{C}_{18: 0}$, stearoyl $\mathrm{C}_{18: 1}$, oleoyl; $\mathrm{C}_{18: 2}$, linoleoyl.

\begin{tabular}{|c|c|c|c|}
\hline \multirow{3}{*}{$\begin{array}{ll}\text { Fatty } & \text { Ifpasc... } \\
\text { acid } & \text { Substrate ... } \\
\text { species } & {[\text { Fatty acid] } \ldots . .}\end{array}$} & \multicolumn{3}{|c|}{ Activity ( $\%$ of control) } \\
\hline & \multirow{2}{*}{$\begin{array}{c}A_{1} \\
1-C_{16: 0}-G P C \\
100 \mu M\end{array}$} & \multicolumn{2}{|c|}{$A_{2}$} \\
\hline & & $\begin{array}{c}2-C_{16: 0}-G P C \\
100 \mu \mathrm{M}\end{array}$ & $\begin{array}{c}2-\mathrm{C}_{20: 4}-\mathrm{GPC} \\
100 \mu \mathrm{M}\end{array}$ \\
\hline $\begin{array}{l}\text { None } \\
C_{16: 0} \\
C_{18: 0} \\
C_{18: 1} \\
C_{18: 2} \\
C_{20: 4}\end{array}$ & $\begin{array}{c}100 \\
44 \pm 8 \\
71 \pm 5 \\
36 \pm 7 \\
37 \pm 4 \\
30 \pm 5\end{array}$ & $\begin{array}{c}100 \\
83 \pm 6 \\
94 \pm 3 \\
62 \pm 4 \\
63 \pm 9 \\
50 \pm 7\end{array}$ & $\begin{array}{l}100 \\
72 \pm 3 \\
86 \pm 7 \\
82 \pm 11 \\
81 \pm 8 \\
78 \pm 10\end{array}$ \\
\hline
\end{tabular}

lysophospholipase $A_{1}$ with palmitoyl-GPC were five times greater than the activities of lysophospholipase $A_{2}$ with 2-palmitoyl-GPC.

\section{DISCUSSION}

The hydrolysis of 1-acyl-GPC by lysophospholipase $A_{1}$ has been described in microsomes isolated from mammalian tissues, including the heart [12-15,25-29]. The present study demonstrates the presence of a lysophospholipase $A_{2}$ that hydrolyses 2-acyl-GPC and has properties distinct from those of lysophospholipase $A_{1}$. The inhibition of lysophospholipases by high concentrations of lysophosphatidylcholine is welldocumented and has been variously suggested to be due to inhibition by micellar aggregates [30], a critical substrate/protein ratio [31], or changes in the membrane characteristics brought about by lysophosphatidylcholine [29]. All the above effects would be expected to affect the two lysophospholipase activities equally if a single enzyme was responsible for both activities. In the present study, however, lysophospholipase $A_{1}$ was inhibited at much lower concentrations of its substrate than was lysophospholipase $\mathbf{A}_{2}$. This phenomenon was observed regardless of whether 2-arachidonoyl- or 2-palmitoyl-GPC was used as the substrate for lysophospholipase $A_{2}$. Although lysophospholipase $A_{1}$ cannot discriminate between 1-acyl-GPC with different fatty acids [12-15], the present study clearly shows that lysophospholipase $\mathrm{A}_{2}$ can discriminate between different species of 2-acyl-GPC, with a preference for 2-linoleoyland 2-arachidonoyl-GPC over 2-oleoyl- and 2-palmitoylGPC when the substrates are presented individually. In attempts to solubilize and purify the enzyme, we have identified two detergents, Miranol DS and Triton QS-15, that do not inhibit the activity. A comparison of the rate of hyrolysis of 2-palmitoyl-GPC and 2-arachidonoylGPC by lysophospholipase $\mathrm{A}_{2}$ in the presence of $0.5 \%$ of these detergents still showed a preference of the enzyme for 2-arachidonoyl-GPC over 2-palmitoyl-GPC (G. Arthur, unpublished work). This observation suggests that the preferential hydrolysis is unlikely to be due to differences in solubility of the substrate or a differential perturbation of the membranes. The ability of the lysophospholipase $\mathbf{A}_{2}$ to differentiate between substrates is also indicated by the differential inhibition of hydrolysis observed when pairs of substrates were presented to the enzyme. The results obtained with mixed substrates, however, lead to the conclusion that the enzyme may not selectively hydrolyse linoleic or arachidonic acids from mixtures of 2-acyl-GPC. Bearing in mind that the degree of inhibition depends on the molar ratio of the mixed lysolipids, the selective inhibition could be a means of regulating the activity of the enzyme with respect to the release of eicosanoid precursors. Thus one can envisage a large and specific release of such fatty acids when a single lysophospholipid is presented, whereas under conditions of general breakdown, when mixed 2-acylGPCs are produced, the release of the precursors will be curtailed. The mechanisms underlying the selective inhibition are unclear and will have to await the purification and elucidation of the mode of regulation of the lysophospholipase A. Both lysophospholipases $A_{1}$ and $A_{2}$ were inhibited to various extents by fatty acids, but lysophospholipase $A_{1}$ was more severely affected than lysophospholipase $A_{2}$. This differential effect was inde- 
pendent of the fatty acid composition of the substrates. All the above evidence suggests that the hydrolysis of 2-acyl-GPC and 1-acyl-GPC is not catalysed by the same enzyme, but direct proof will have to await the purification of both enzymes.

The cellular function of the lysophospholipase A is not known; however, the high activity exhibited with 2-acylGPC with linoleate and arachidonate raises the possibility that such an enzyme could work in concert with phospholipase $A_{1}$ to release specific fatty acids such as arachidonic acid or linoleic acid for the cyclo-oxygenase or lipoxygenase pathways. The existence of such a pathway, in addition to the phospholipase $A_{2}$ release mechanism, could allow cells to mobilize fatty acids from different phospholipid classes and/or subclasses in response to different stimuli. The release via phospholipase $A_{1}$ and lysophospholipase $A_{2}$ would permit a more flexible response by the cells, since the specificity of the fatty acid released, as well as the rate of release, could be controlled at both the phospholipase $A_{1}$ and lysophospholipase levels. It has recently been demonstrated that hydrolysis of the C-1 bond of a phospholipid can depend on the nature of the fatty acid at both the C-1 and C-2 position [11]. Thus the selective hydrolysis of a particular molecular species by such a phospholipase $\mathrm{A}_{1}$ would produce a single species of 2-acyl-GPC that can be hydrolysed by the lysophospholipase $A_{2}$ to mobilize a single species of fatty acid. On the other hand, hydrolysis by a non-discriminating phospholipase $A_{1}$ would yield a mixed population of 2-acyl-GPC. The relative composition of the 2-acyl-GPC could influence the rates of release of various fatty acids and could thereby regulate the quantity of substrates available for the lipoxygenase or cyclo-oxygenase pathways.

I thank Mrs. L. Page for technical assistance and Dr. N. Fleming for critically reading the manuscript. This work was supported by a grant from the Manitoba Heart Foundation and a Medical Research Council Scholarship to G.A.

\section{REFERENCES}

1. Smith, W. L. \& Borgeat, P. (1985) in Biochemistry of Lipids and Membranes (Vance, D. E. \& Vance, J. E., eds.), pp. 325-360, Benjamin/Cummings, Menlo Park, CA

2. Irvine, R. F. (1982) Biochem. J. 204, 3-16

3. Buchanan, M. R., Butt, R. W., Magas, Z., Van Ryn, J., Hirsh, J. \& Nazir, D. J. (1985) Thromb. Haemostasis 53, 306-311

4. Buchanan, M. R., Haas, T. A., Lagarde, M. \& Guichardant, M. (1985) J. Biol. Chem. 260, 16056-16059 5. Gross, R. W. (1984) Biochemistry 23, 158-165

Received 4 June 1988/23 January 1989; accepted 31 January 1989
6. Arthur, G., Mock, T., Zaborniak, C. \& Choy, P. C. (1985) Lipids 20, 693-698

7. Lokesh, B. R. \& Kinsella, J. E. (1985) Biochim. Biophys. Acta 845, 101-108

8. Pollock, W. R., Rink, T. J. \& Irvine, R. F. (1986) Biochem. J. 235, 869-877

9. Snyder, F. (1985) in Biochemistry of Lipids and Membranes (Vance, D. E. \& Vance, J. E., eds.), pp. 271-298, Benjamin/Cummings, Menlo Park, CA

10. Van den Bosch, H. (1980) Biochim. Biophys. Acta 604, 191-246

11. Cao, Y.-Z., Tam, S. W., Arthur, G., Chen, H. \& Choy, P. C. (1987) J. Biol. Chem. 262, 16927-16935

12. Van den Bosch, H., Aarsman, A. J., Slotboom, A. J. \& Van Deenen, L. L. M. (1968) Biochim. Biophys. Acta 164, 215-225

13. Sun, G. Y., Tang, W., Huang, S. F.-L. \& MacQuarrie, R. (1987) Neurochem. Res. 12, 451-458

14. De Jong, J. G. N., Van Den Bosch, H., Aarsman, A. J. \& Van Deenen, L. L. M. (1973) Biochim. Biophys. Acta 296, 105-115

15. Van den Bosch, H. (1982) in Phospholipids (Hawthorne, J. N. \& Ansell, G. B., eds.), pp. 313-357, Elsevier Biomedical Press, Amsterdam

16. Dennis, E. A. (1983) Enzymes 3rd Ed. 16, 307-353

17. Lowry, O. H., Rosebrough, M. J., Farr, A. L. \& Randall, R. J. (1951) J. Biol. Chem. 193, 265-275

18. Hermetter, A. \& Paltauf, F. (1982) Chem. Phys. Lipids 30, 47-53

19. Arthur, G., Page, L., Mock, T. \& Choy, P. C. (1986) Biochem. J. 236, 475-480

20. Bartlett, G. R. (1959) J. Biol. Chem. 234, 466-468

21. Colard, O., Breton, M. \& Bereziat, G. (1986) Biochem. J. 233, 691-695

22. Fauvel, J., Bonnefis, M. J., Sarda, L., Chap, H., Thouvenot, J.-P. \& Douste-Blazy, L. (1981) Biochim. Biophys. Acta 663, 446-456

23. Sheltawy, A. S. \& Dawson, R. M. C. (1969) in Chromatographic and Electrophoretic Techniques (Smith, I., ed.), vol. 1, pp. 453-493, Heinemann, London

24. Arthur, G. (1989) Biochem. J. 261, 575-580

25. Gross, R. W. \& Sobel, B. E. (1983) J. Biol. Chem. 258, 5221-5226

26. Severson, D. L. \& Fletcher, T. (1985) Can. J. Physiol. Pharmacol. 63, 944-951

27. Giffin, M., Arthur, G., Choy, P. C. \& Man, R. Y. K. (1988) Can. J. Physiol. Pharmacol. 66, 185-189

28. Leti, U. \& Hauser, G. (1987) Biochim. Biophys. Acta 918, 126-135

29. Gross, R. W. \& Sobel, B. E. (1982) J. Biol. Chem. 257, 6702-6708

30. Leibovitz-Ben Gershon, Z. \& Gatt, S. (1972) J. Biol. Chem. 247, 6840-6847

31. Leibovitz-Ben Gershon, Z. \& Gatt, S. (1973) J. Biol. Chem. 248, 1525-1529 